San Jose State University

From the SelectedWorks of Sen Chiao

September 11, 2013

Case studies of tropical cyclones and phytoplankton blooms over Atlantic and Pacific regions

Ashley M. Merritt-Takeuchi, Covance Inc.

Sen Chiao, San Jose State University 


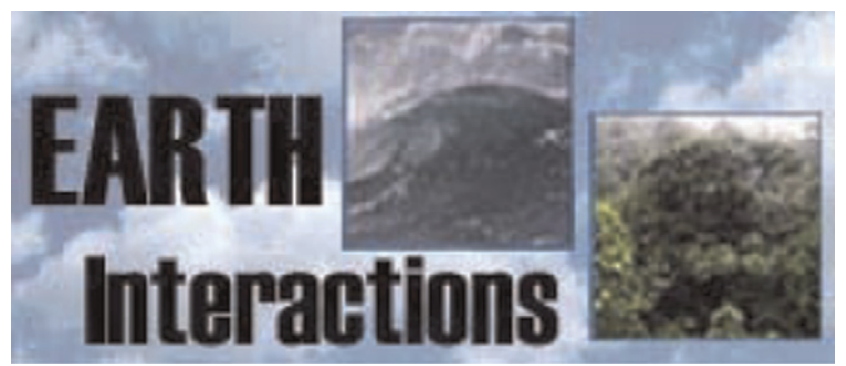

Copyright (c) 2013, Paper 17-017; 34053 words, 10 Figures, 0 Animations, 2 Tables. http://EarthInteractions.org

\title{
Case Studies of Tropical Cyclones and Phytoplankton Blooms over Atlantic and Pacific Regions
}

\section{Ashley M. Merritt-Takeuchi}

Informatics Modeling, Operational Strategy and Planning, Covance, Inc., Nashville, Tennessee

\section{Sen Chiao*}

Department of Meteorology and Climate Science, San Jose State University, San Jose, California

Received 17 January 2013; accepted 22 May 2013

\begin{abstract}
This study investigates phytoplankton blooms following the passage of tropical cyclones in the Atlantic and Pacific Ocean basins. The variables of sea surface temperature (SST), chlorophyll (Chl-a), precipitation, and storm surface winds were monitored for two case studies, Typhoon Xangsane (2006) and Hurricane Earl (2010). Strong near-surface wind from tropical cyclones creates internal friction, which causes deep nutrient enriched waters to displace from the bottom of the ocean floor up toward the surface. In return, the abundance of upwelled nutrients near the surface provides an ideal environment for the growth of biological substances such as chlorophyll and phytoplankton. The inverse correlation coefficients of SST and Chl- $a$ for this study are -0.67 and -0.26 for Xangsane and Earl, respectively. This suggests that, regardless of ocean basin, changing sea surface temperature and chlorophyll concentrations can be correlated to various characteristics of tropical
\end{abstract}

* Corresponding author address: Dr. Sen Chiao, Meteorology and Climate Science, San Jose State University, San Jose, CA 95192-0104.

E-mail address: sen.chiao@sjsu.edu 
Earth Interactions - Volume 17 (2013) • Paper No. 17 • Page 2

cyclones including precipitation and surface wind, which in combination results in an increase of phytoplankton.

KEYWORDS: Tropical cyclones; Phytoplankton; Sea surface temperature

\section{Introduction}

The near-surface wind from tropical cyclones is one of the driving factors for deep-water upwelling, which brings an abundance of nutrient enriched sediments to the surface. Because of divergence generated by major storms, the water columns mixed layer deepens and brings cooler water to the surface, which can be evident within days following the passage of a tropical cyclone (e.g., Price 1981; Babin et al. 2004; Son et al. 2007; Lin et al. 2003). With cooler water aloft and additional localized sediments, chlorophyll and phytoplankton concentrations can increase (Katara et al. 2008). Implications from phytoplankton blooms may result in adverse effects on aquatic species and their ecosystems (Monaldo et al. 1997). One significant impact includes the blockage of incoming solar radiation, which results in a disturbance of the aquatic habitat (Diersing 2009). In particular, the lack of sunlight affects the growth of sea grasses located on the ocean floor that is a provider of essential nutrients for various organisms. Consequently, phytoplankton blooms can significantly affect the population of species dependent on those nutrients. Wang and Zhao (Wang and Zhao 2008) investigated phytoplankton variations in the Arabian Sea associated with Hurricane Gonu (2007) and concluded that blooms may attribute to storm-induced nutrient uptake as similarly examined by Livingston (Livingston 2007). Shi and Wang (Shi and Wang 2007) investigated hurricane-induced phytoplankton bloom in the Gulf of Mexico and pointed out that a notable phytoplankton bloom in the Gulf of Mexico was observed 4 days after the passage of Hurricane Katrina. Acker et al. (Acker et al. 2009) further concluded that, during the life cycle of Katrina, phytoplankton blooms enhanced nutrient supply brought up by wind-driven upwelling and vertical mixing and were identified as the only source of observed changes in ocean optical and bio-optical properties.

Nevertheless, phytoplankton blooms in association with sea surface temperatures (SST) and tropical cyclone intensity over the western Pacific and North Atlantic basins are still worthwhile for documenting. The goal of this study is to examine and document phytoplankton blooms through the usage of remote sensing data by comparing changes in SST, chlorophyll (Chl- $a$ ), maximum surface winds, and precipitation following the passage of tropical cyclones located in both the Atlantic and Pacific Ocean basins. The objectives of this study include the following: 1) examine the response of phytoplankton bloom variations in different tropical basins during the event of a subtropical cyclone and 2) demonstrate that correlations among SST, tropical cyclone intensity, and phytoplankton blooms can be distinguished by the passage of tropical cyclones. Two case studies, Typhoon Xangsane (2006) and Hurricane Earl (2010) were investigated. Section 2 will focus on the methodology and case descriptions. Section 3 will detail each case study through remote sensing observation, and section 4 will conclude all findings.

\section{Methodology and case descriptions}

In this study, tropical cyclones were chosen based on maximum wind speeds greater than $130 \mathrm{mph}$ or $\sim 58 \mathrm{~m} \mathrm{~s}^{-1}$ (i.e., category 4) and storm paths that passed 
Earth Interactions - Volume 17 (2013) • Paper No. 17 • Page 3

over or nearby land. Storm features were chosen to provide a similar analysis based on landmass and storm intensity. Because of the large presence of clouds during tropical cyclones, composite imagery was used to account for cloud contamination. Since the utilization of remote sensing, cloud contamination has been a limiting factor to monitoring surface data. According to Ahmad and Quegan (Ahmad and Quegan 2012), on average, 50\% of Earth's atmosphere is obstructed by clouds each day; therefore, distinguishing cloud contamination is essential for research involving satellite-derived imagery. To eliminate cloud contamination, a cloudmasking product known as Moderate Resolution Imaging Spectroradiometer (MODIS) Cloud Mask was used in combination with 1-km Aqua MODIS data by generating an algorithm to examine sequences of visible and infrared thresholds (cf. MODIS Atmosphere 2013). Through the utilization of cloud-masking software, clearer imagery unbiased to scientific error was obtainable.

SST and Chl- $a$ were generated with National Oceanic Atmospheric Administration (NOAA) online database of Environmental Research Division Data Access Program (ERDDAP), and 14-day composites of SST and Chl- $a$ for Typhoon Xangsane were created from satellite data obtained by Aqua MODIS. High-resolution (i.e., $1 \mathrm{~km}$ ) imagery of SST for Hurricane Earl was generated by the National Aeronautics and Space Administration (NASA) Jet Propulsion Laboratory (JPL) Regional Ocean Modeling System (NASA 2011a), and an 8-day composite from Aqua MODIS was generated for Chl- $a$ (NOAA ERDDAP 2011). The storm paths of Typhoon Xangsane and Hurricane Earl were plotted using Weather Underground's tropical cyclone tracking application (Weather Underground 2013a; Weather Underground 2013b). Surface winds and precipitation were generated for a 4-day period to compare values during the passage of each event. Precipitation plots were based on the NASA Tropical Rainfall Measuring Mission (TRMM) Real-Time Multisatellite Precipitation Analysis for experimental 3-h rainfall amounts (i.e., 3B42RT; NASA 2011b), and imagery for surface winds was created from the Blended Sea Winds products (Zhang and Bates 2011), which is composed of multiple-satellite observations.

\subsection{Pacific region: Typhoon Xangsane (2006)}

On 25 September 2006, an area of convection developed into a tropical depression located $322 \mathrm{~km}$ east of the Philippians (Dunbar 2011). Within 36 h, this tropical depression rapidly intensified to a category 4 typhoon. Upon passing through the Philippian Islands, the storm weakened due to land interactions. However, it reintensified over the warm surface waters of the South China Sea (Lana 2007). As Xangsane approached the coast of Vietnam, maximum sustained wind peaked to $145 \mathrm{mph}\left(\sim 64.8 \mathrm{~m} \mathrm{~s}^{-1}\right)$. By 1 October, Typhoon Xangsane made landfall in Vietnam and then quickly dissipated on 2 October (Figure 1a).

\subsection{Atlantic region: Hurricane Earl (2010)}

On 23 August 2010, along the western coast of Africa, an area of low pressure developed and moved toward the Atlantic Ocean as a strong tropical wave (Cangialosi and Franklin 2012). Because of deep convection within the region of thunderstorms, the easterly wave further developed and was categorized as a 

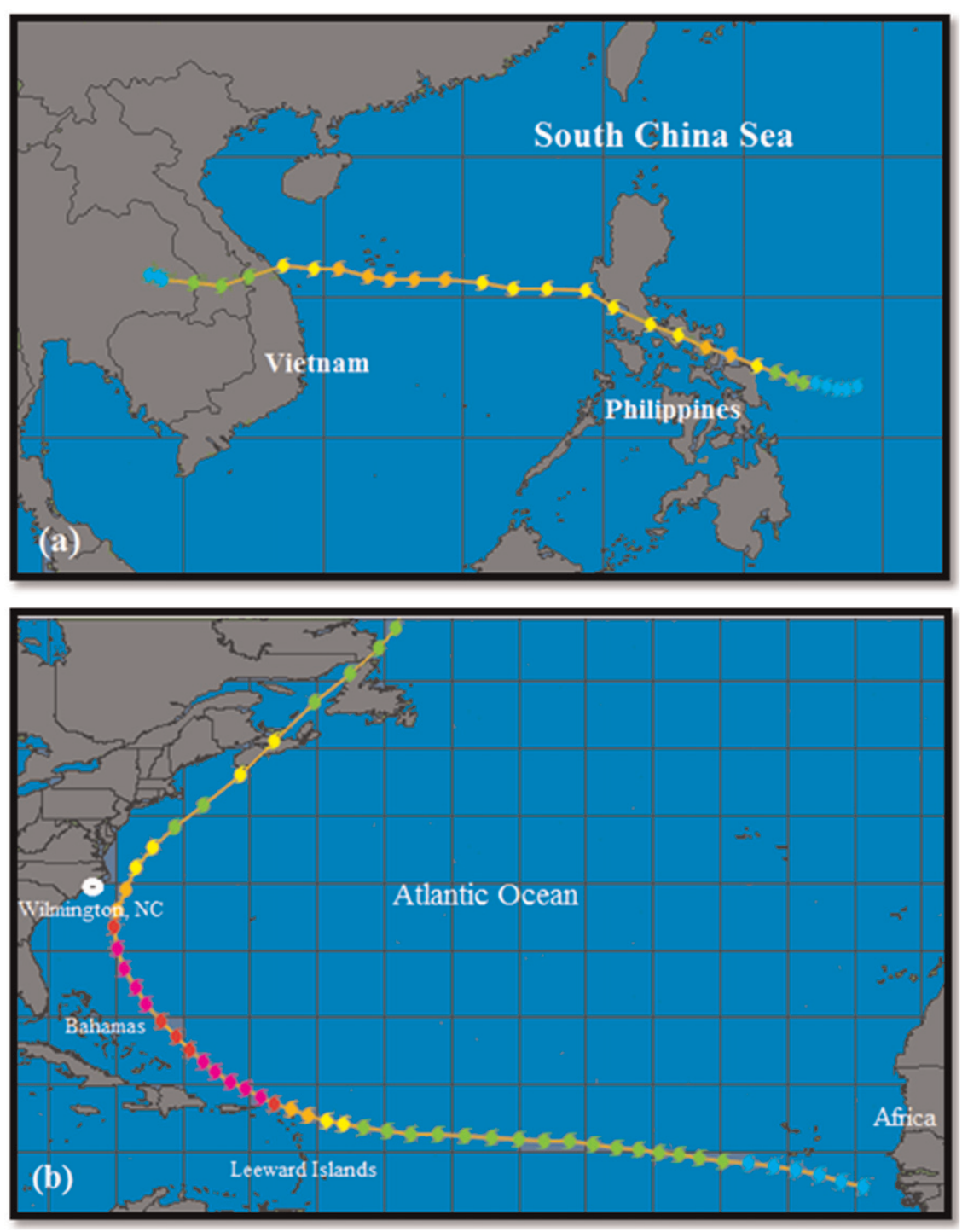

Figure 1. (a) South China Sea Typhoon Xangsane plotted path from Weather Underground's tropical cyclone tracker for 26-30 Sep 2006. (b) Atlantic Ocean Hurricane Earl plotted path from 25 Aug to 4 Sep 2010.

tropical depression at 1200 UTC 25 August. As the tropical depression headed westward, it gained intensification because of warm sea surface temperatures and relatively moderate wind stress. On 29 August, the tropical depression was located about $407 \mathrm{~km}$ east of the Leeward Islands and was upgraded to a hurricane. The change in storm direction from the west to northwest was caused by a disturbance in the subtropical ridge from the remnants of Hurricane Danielle. Located north of the Leeward Islands, Hurricane Earl strengthened into a category 3 system at 0000 UTC. Within 8 h, Earl was upgraded to a category 4 hurricane at 1800 UTC (Figure 1b). The intensity of the storm reduced on 31 August because of wind shear and then reintensified when located $700 \mathrm{~km}$ to the southwest of Wilmington, 


\section{Earth Interactions • Volume 17 (2013) • Paper No. 17 • Page 5}

North Carolina, on 1 September (Cangialosi and Franklin 2012). Following the passage of Hurricane Earl beyond the North Carolina coast, Earl rapidly weakened, as a by-product of cooler SST and drier air. The weakened storm continued northward and was located to the southeast of Long Island at 0000 UTC 4 September. By 1200 UTC, Earl reintensified again and made landfall as a weak hurricane near Nova Scotia. The dissipation of Earl occurred on 5 September when an upperlevel low interacted with the remnants of the storm. A more detailed synoptic overview of Hurricane Earl can be obtained at the National Hurricane Center.

\section{Remote sensing measurements}

\subsection{Typhoon Xangsane (2006)}

\subsubsection{Comparison of sea surface temperature and chlorophyll}

As tropical cyclones pass through oceanic basins, decreases in SST often occur because of strong forcing of wind shear near the surface (Jacob and Shay 1999). Composite SST imagery in Figure 2 shows the response of temperature changes surrounding the case of Typhoon Xangsane. A 14-day composite from 27 September to 16 October 2006 derived from Aqua MODIS data was used to display prior storm motion, passage, and feedback responses. We will focus on the target area $\left(13.0^{\circ}-\right.$ $17.0^{\circ} \mathrm{N}, 108^{\circ}-114^{\circ} \mathrm{E}$ ) to illustrate differences in concentration prior, during, and after the event of Xangsane (Figure 3).

In Figure 4a, the time evolution of SST is displayed. The daily values (Table 1) were determined by calculating the overall numerical average from our sectional target region. The data were obtained from the NOAA Easier Access to Scientific Data's (ERDDAP) online database. The first evident change in SST is shown on 30 September. Typhoon Xangsane passed the target area around 1200 UTC and caused a decrease of $1.6^{\circ} \mathrm{C}$ within a $24-\mathrm{h}$ period. The following day (1 October), the averaged SST for the same location reached a minimum value of $25.7^{\circ} \mathrm{C}$ as shown in Figure 4a. The period after 1 October demonstrated gradual increases in SST and returned to quasi-normal values by 15 October.

The time evolution of averaged Chl- $a$ over the target area is shown in Figure 4b. On 30 September, the tropical cyclone passed into the target area (Figure 3). For this date, Chl- $a$ peaked to the second highest average value of $0.50241 \mathrm{mg} \mathrm{m}^{-3}$ (Figure 4b). This resulted in an increase of $0.27327 \mathrm{mg} \mathrm{m}^{-3}$ from the prestorm concentration of $0.22913 \mathrm{mg} \mathrm{m}^{-3}$ (27 September). The data series in Figure 4a, on 30 September, illustrate an inverse correlation [i.e., negative SST cooling $\left(-1.6^{\circ} \mathrm{C}\right)$ with increasing Chl-a]. As cloud cover became less dominate with time (not shown), clearer imagery of chlorophyll was obtainable in the following days. In particular, concentrations remained within the range of $0.4700 \mathrm{mg} \mathrm{m}^{-3}$ from 1 to 5 October. On 6 October, values dropped from 0.4675 to $0.40349 \mathrm{mg} \mathrm{m}^{-3}$, which we believe was associated with oceanic circulation within the water column. On 13 October, the observed concentration was $0.2319 \mathrm{mg} \mathrm{m}^{-3}$, similar to the prestorm value of $0.22913 \mathrm{mg} \mathrm{m}^{-3}$.

Table 1 compares the daily averages of SST and Chl- $a$ to numerically display the correlation between decreasing SST and increasing Chl- $a$ concentrations. As discussed, the initial increase of Chl- $a$ between 28 and 29 September does not appear 

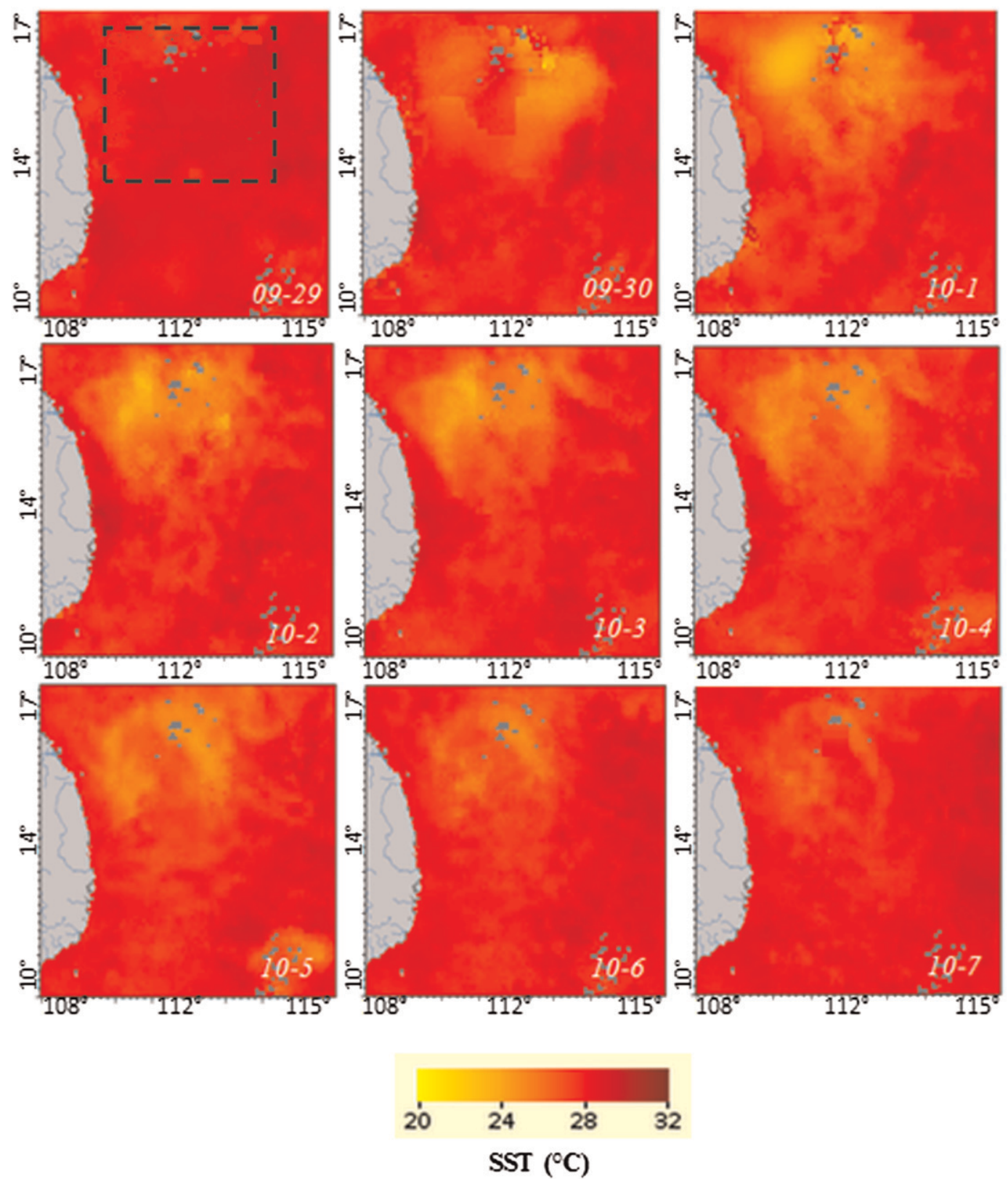

Figure 2. Daily sea surface temperature from Aqua MODIS in the South China Sea following the passage of Typhoon Xangsane from 29 Sep to 7 Oct 2006. The box area represents the region of interest for maximum variations in sea surface temperature.

to be induced by deep upwelling of the ocean mixed layer since SST remained at a constant temperature of $28^{\circ} \mathrm{C}$ between 27 and 29 September. Subrahmanyam et al. (Subrahmanyam et al. 2002) conducted a similar study, which focused on the influence of tropical cyclone-induced variations in phytoplankton biomass in the Arabian Sea and noted comparable lag time between Chl- $a$ concentrations and 


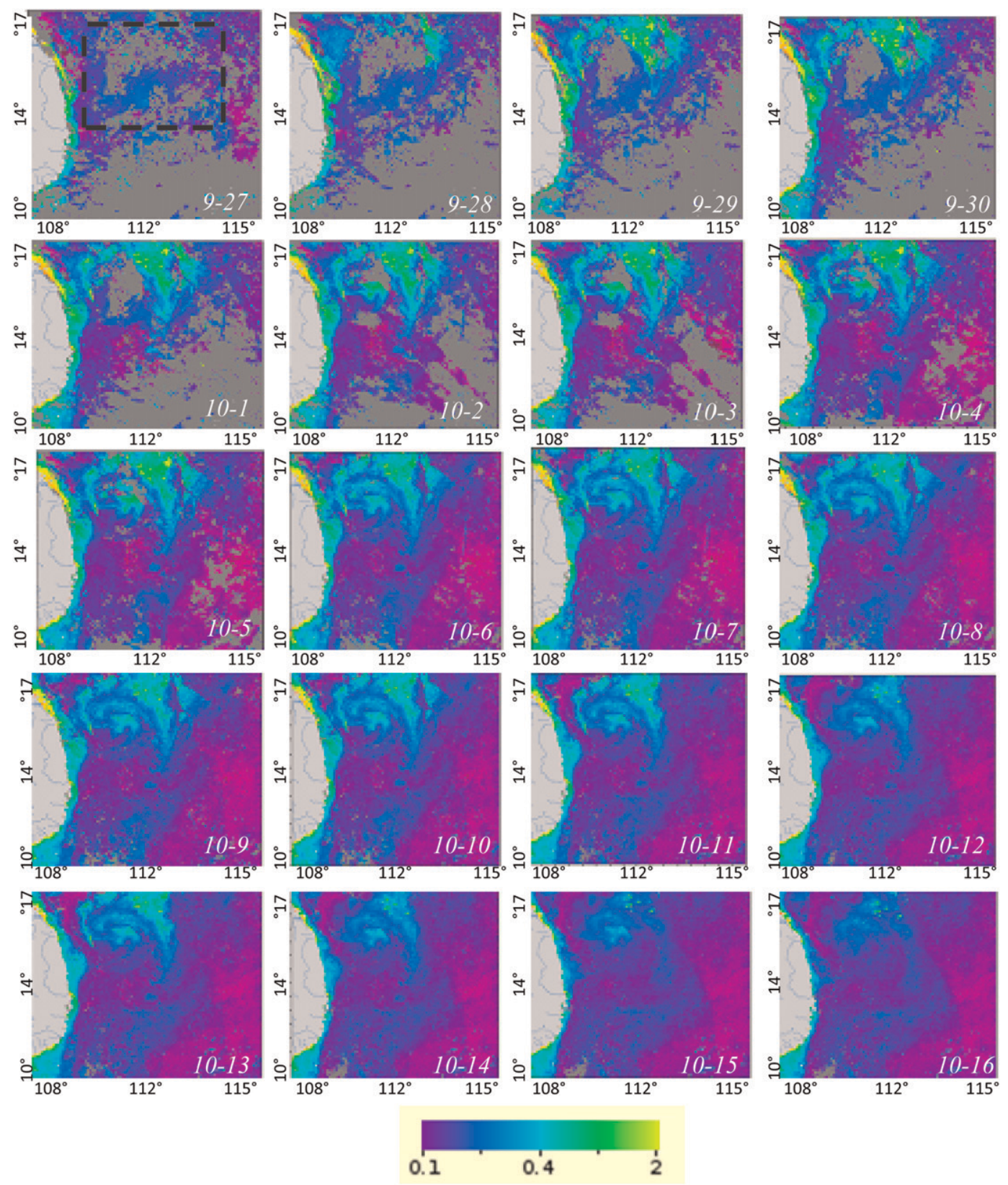

Chlorophyll (mg/m $\left.\mathbf{m}^{3}\right)$

Figure 3. Composite imagery of chlorophyll derived from satellite data from Aqua MODIS. Dates include 27 Sep-16 Oct 2006 for the case study of Typhoon Xangsane. The box area represents the location that exhibited large changes in chlorophyll concentrations. 
(a)

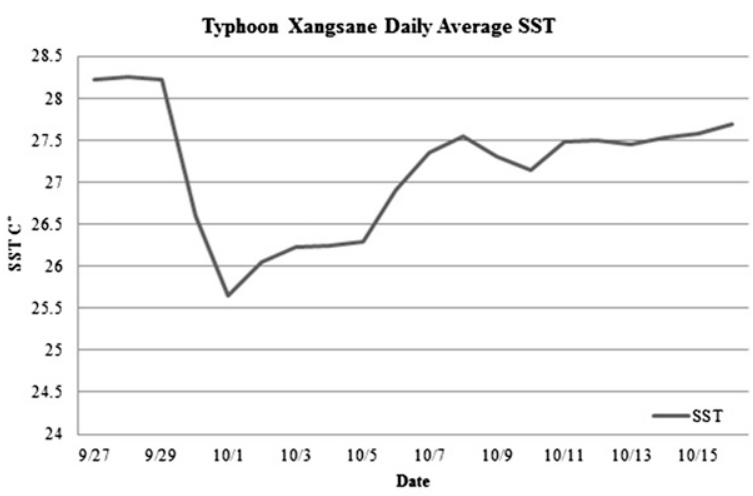

(b)

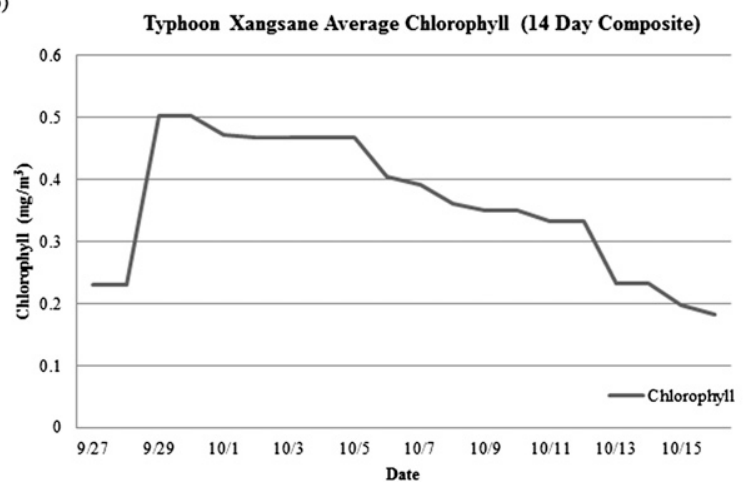

Figure 4. (a) Averaged daily SST and (b) averaged daily Chl- $a$ for box area from 27 Sep to 15 Oct 2006.

decreasing SST. Additionally, research illustrated from Hanshaw et al. (Hanshaw et al. 2008) on integrated impacts of tropical cyclones on SST and Chl- $a$ utilized the Sea-viewing Wide Field-of-view Sensor (SeaWiFS) to examine the correlation of subsurface chlorophyll abundance prior to the passage of hurricanes in the Atlantic Ocean. Overall, this suggests that surface wind shear from subtropical events can result in the rising concentration levels of Chl- $a$ prior to the decrease in SST. Consequently, it has been documented that surface wind shear can mix sediments located at various depths within the water column, resulting in the transfer of particulates in shallower locations prior to the deepening of the mixed layer (e.g., Diersing 2009).

\subsubsection{Four-day comparison}

The intent of the 4-day comparison was to document the changes that occurred during the passage of Typhoon Xangsane based on surface wind and precipitation (Figure 5). Images were plotted daily between 0000 and 1200 UTC for precipitation and at 0600 UTC for wind fields. The timeline for this analysis included 28 September (1 day prior to the passage), 29-30 September (storm passage), and 1 October (poststorm). 


$$
\text { Earth Interactions - Volume } 17 \text { (2013) - Paper No. } 17 \text { • Page } 9
$$

Table 1. Daily averaged chlorophyll and sea surface temperatures calculated for the box region derived from ERDDAP numerical values from 27 Sep to 16 Oct 2006 for the case study of Typhoon Xangsane. Highlighted box denotes 4-day analysis (28 Sep-1 Oct 2006) in box region for Chl-a, SST, maximum wind, and average precipitation.

\begin{tabular}{lccccrcc}
\hline \multicolumn{1}{c}{ Date } & $\begin{array}{c}\text { Chl- } a \\
\left(\mathrm{mg} \mathrm{m}^{-3}\right)\end{array}$ & SST $\left({ }^{\circ} \mathrm{C}\right)$ & $\begin{array}{c}\text { Maximum } \\
\text { wind }\left(\mathrm{m} \mathrm{s}^{-1}\right)\end{array}$ & $\begin{array}{c}\text { Average } \\
\text { precipitation }(\mathrm{mm})\end{array}$ & Date & $\begin{array}{c}\text { Chl- } a \\
\left(\mathrm{mg} \mathrm{m}^{-3}\right)\end{array}$ & SST $\left({ }^{\circ} \mathrm{C}\right)$ \\
\hline 27 Sep & 0.22913 & 28.21 & & & 7 Oct & 0.39166 & 27.35 \\
\hline 28 Sep & 0.22926 & 28.25 & 6 & 2.56 & 8 Oct & 0.36064 & 27.53 \\
29 Sep & 0.50319 & 28.21 & 11 & 28.1 & 9 Oct & 0.35076 & 27.28 \\
30 Sep & 0.50241 & 26.58 & 25 & 38.39 & 10 Oct & 0.34967 & 27.12 \\
1 Oct & 0.47291 & 25.62 & 16 & 1.47 & 11 Oct & 0.33286 & 27.48 \\
2 Oct & 0.46864 & 26.01 & & & 12 Oct & 0.33286 & 27.49 \\
3 Oct & 0.46864 & 26.19 & & & 13 Oct & 0.23196 & 27.45 \\
4 Oct & 0.4679 & 26.21 & & & 14 Oct & 0.23202 & 27.51 \\
5 Oct & 0.46759 & 26.26 & & & 16 Oct & 0.19862 & 27.57 \\
6 Oct & 0.40349 & 26.88 & & & & & \\
\hline
\end{tabular}

The analysis begins on 28 September, which signifies the conditions prior to the arrival of Xangsane. Overall, each examined feature showed relatively stable conditions on this date. On 29 September, the tropical cyclone advanced into the target area as shown by the typhoon winds and heavy precipitation (Figure 5). The surrounding center region of the storm reached maximum sustained surface winds of $25 \mathrm{~m} \mathrm{~s}^{-1}$ and accumulated a total rainfall amount of $38.39 \mathrm{~mm}$. For SST, little or no change occurred (Figure 2); however, Chl- $a$ began to gradually increase.

On 30 September, Xangsane rapidly approached the coast of Vietnam. Heavy precipitation and surface winds continued to persist in the area. Conditions of the storm weakened near land, but the water region to the right showed significant changes. SST displayed a large decrease in temperature $\left(-1.6^{\circ} \mathrm{C}\right)$, while Chl- $a$ increased $\left(+0.2741 \mathrm{mg} \mathrm{m}^{-3}\right)$ as shown in the highlighted box of Table 1. On the final day (1 October), SST reached a minimum value of $25.6^{\circ} \mathrm{C}$ (Figure 2) while Chl- $a$ became more abundant and widespread.

\subsubsection{Precipitation and wind field}

Although limited information is available on how precipitation affects phytoplankton blooms in open body waters, total rainfall accumulation can be interrelated with surface winds and changes in the mixed layer (Jacob and Koblinsky 2007). Additionally, heavy precipitation over land can cause direct runoff of sediments into rivers, estuaries, and oceans, providing added nutrients that can increase Chl- $a$ concentrations along coastal areas (Zhao et al. 2009; Zheng and Tang 2007). Consequently, our data suggest that runoff of heavy rainfall accumulation on land may be a contributing factor to the large concentrations of Chl- $a$ seen after the storm passage (i.e., 1 October).

The most notable change in Chl- $a$ occurred prior to the decrease in SST on 29 September, which we believe was influenced by the impacts of surface wind. Storm-induced shear forcing can have significant effects on the water column. Horizontal stress acting upon the surface water can directly contribute to vertical upwelling and displacement by methods of the Ekman spiral. In addition, the 
Surface Wind
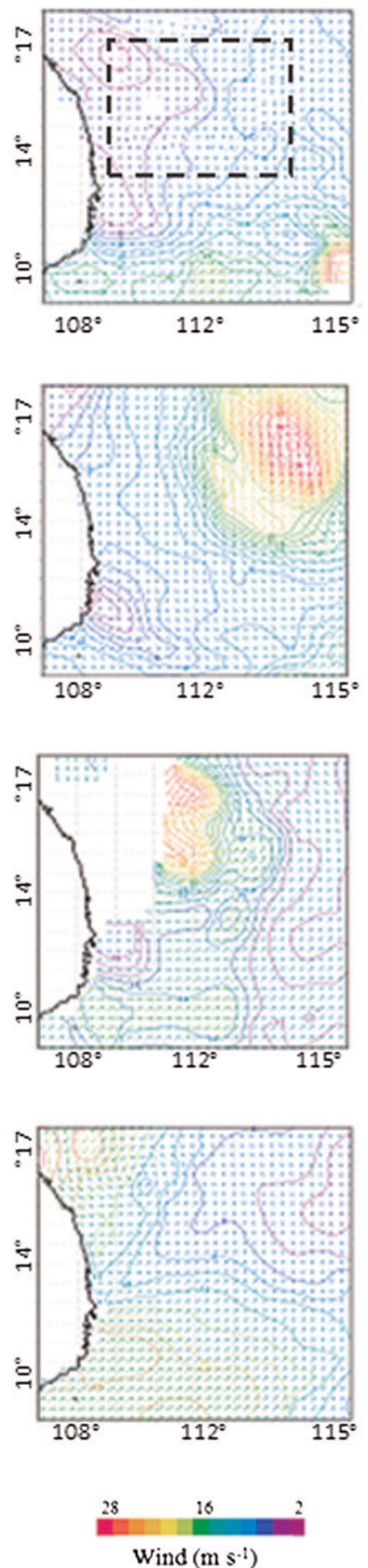

\section{Precipitation}
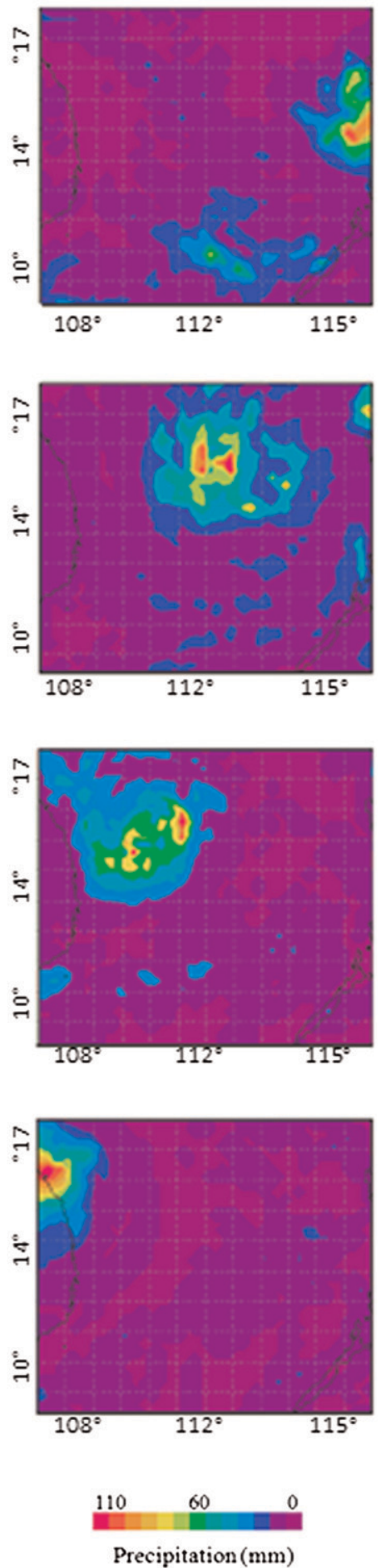

Figure 5. A 4-day comparison of precipitation based on the TRMM Real-Time Multisatellite Precipitation Analysis for experimental 3-hourly rainfall, with surface winds generated by the Blended Sea Winds, for the passage of Typhoon Xangsane from 1 Sep to 1 Oct 2006. 
Earth Interactions - Volume 17 (2013) • Paper No. 17 • Page 11

formation of eddies can often occur as the water column changes speed and orientation, which in return can cause further displacement and accumulation of chlorophyll (Basterretxea et al. 2002).

\subsection{Hurricane Earl (2010)}

\subsubsection{Sea surface temperature and chlorophyll evolutions}

This analysis investigates changing SST from 1 to 14 September 2010 (Figure 6). The dates chosen accounted for 2 days prior to (1-2 September), during (3 September), and after the storm (4-14 September). The target area $\left(31.8^{\circ}-34.5^{\circ} \mathrm{N}\right.$, $\left.284^{\circ}-287.5^{\circ} \mathrm{E}\right)$ represents the location where most significant variations occurred.

Numerical values of SST and Chl- $a$ were monitored for 15 days. The comparison of SST and Chl- $a$ provides evidence of a correlation between decreasing SST and increasing Chl- $a$ resulting from the passage of Earl. According to calculated averages, SST initially cooled on 3 September reaching a minimum temperature of $25.9^{\circ} \mathrm{C}$ on 7 September (Table 2). Analysis between the start date (1 September) and minimum value ( 7 September) displayed a temperature decrease by $2.0^{\circ} \mathrm{C}$. Examining the days after the minimum value showed a "plateau" effect. This feature was further investigated by evaluating the temperature field, which remained relatively constant from 7 to 11 September (not shown). Since nutrients were present near the surface, it may have taken time for upwelled sediments to sink to the ocean floor, accounting for the constant value on the graph (Diersing 2009).

The change in Chl- $a$, estimated by satellite-based estimates from 31 August to 14 September 2010, is presented by satellite-derived imagery (Figure 7). Studying this timeline allowed us to examine 2 days prior to (31 August-2 September), during (3-9 September), and after the storm (4-14 September). The target area $\left(31.8^{\circ}-34.5^{\circ} \mathrm{N}, 284^{\circ}-287.5^{\circ} \mathrm{E}\right)$ represents the location where maximum changes in SST and Chl- $a$ occurred. The daily values (Table 2 ) were determined by calculating the overall numerical average from our sectional target region. These data were obtained from the NOAA Easier Access to Scientific Data (ERDDAP) online database. For this particular case, large concentrations accumulated in the region of the Bahamas and areas along the eastern coastline. We believe that this feature occurred because of the shallow depth of the water column located along the coastline (coastal upwelling). Sediments that lie along the ocean bed in shallower regions can easily be upwelled to the surface by sea winds since the distance of sediment transport is much less; therefore, a larger abundance of chlorophyll occurs (Emelyanov 2005). Overall, the most significant correlation is evident on 3 September (Figures 8a,b). This validates our expectation of opposing trends due to oceanic response to the tropical cyclone. In addition, minimum (SST) and maximum (Chl- $a$ ) values both peaked on 5 September because of strong hurricane winds that resulted in cooler nutrient enriched surface waters.

\subsubsection{Four-day comparison}

The intent of the 4-day comparison was to emphasize the changes that occurred during the passage of Hurricane Earl based on surface wind and precipitation (Figure 9). The timeline for this analysis included the following: 2 September 
Earth Interactions - Volume 17 (2013) - Paper No. 17 • Page 12
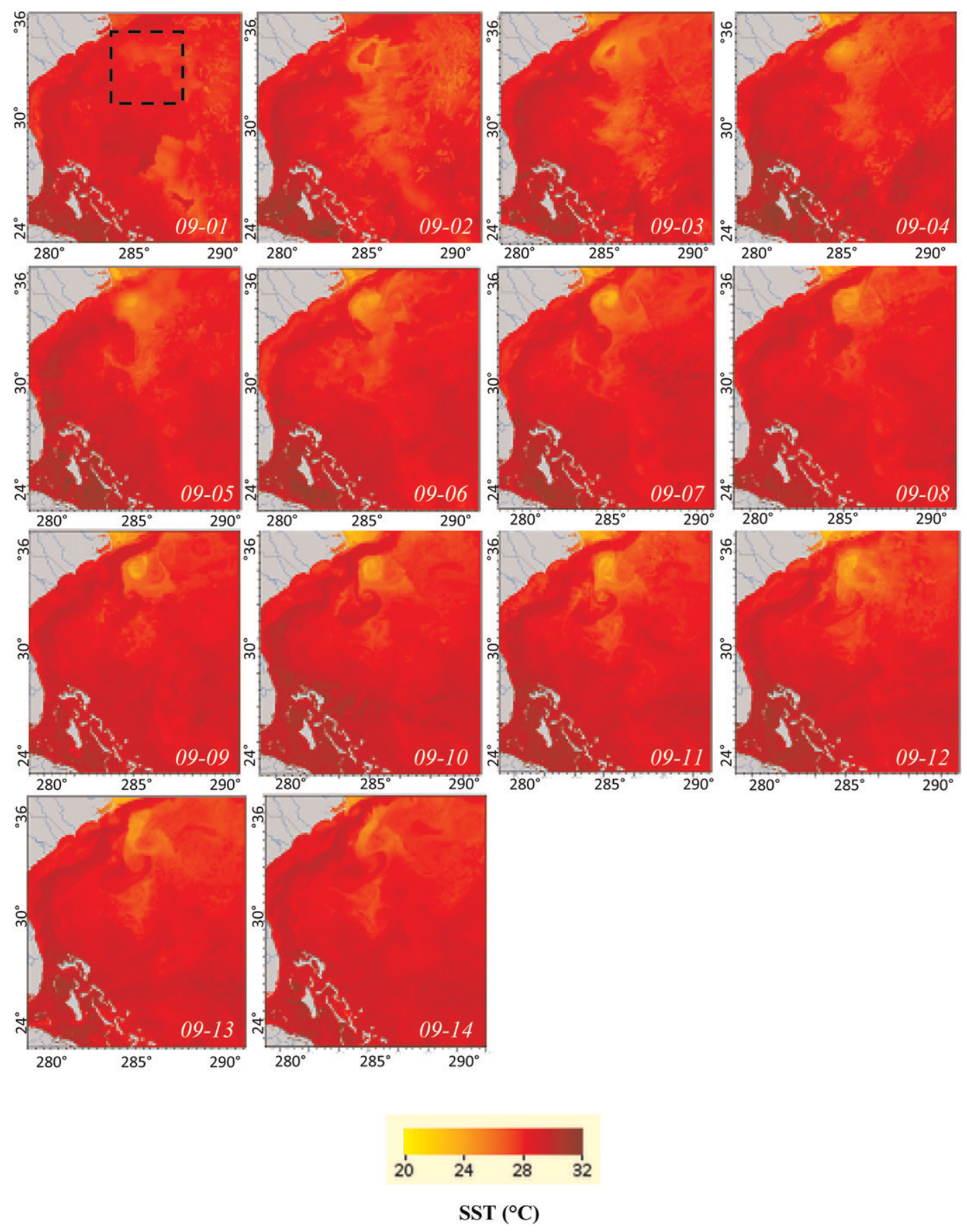

Figure 6. Daily sea surface temperature derived from very-high-resolution (1 km) satellite data in the Atlantic Ocean following the passage of Hurricane Earl from 1 to 14 Sep 2010. The boxed area represents the region of interest (i.e., target area) for variations in sea surface temperature. 
Earth Interactions V Volume 17 (2013) • Paper No. 17 • Page 13

Table 2. Daily averaged chlorophyll and sea surface temperatures calculated for the box region derived from ERDDAP numerical values from 31 Aug to 14 Sep 2010 for the case study of Hurricane Earl. Highlighted box denotes 4-day analysis (2-5 Sep 2010) in white box region for Chl-a, SST, maximum wind, and average precipitation.

\begin{tabular}{lccccccc}
\hline \multicolumn{1}{c}{ Date } & $\begin{array}{c}\mathrm{Chl}-a \\
\left(\mathrm{mg} \mathrm{m}^{-3}\right)\end{array}$ & SST $\left({ }^{\circ} \mathrm{C}\right)$ & $\begin{array}{c}\text { Maximum wind } \\
\left(\mathrm{m} \mathrm{s}^{-1}\right)\end{array}$ & $\begin{array}{c}\text { Average } \\
\text { precipitation }(\mathrm{mm})\end{array}$ & $\begin{array}{c}\text { Date } \\
\left(\mathrm{mg} \mathrm{m}^{-3}\right)\end{array}$ & SST $\left({ }^{\circ} \mathrm{C}\right)$ \\
\hline 31 Aug & 0.06919 & 27.99 & & & 8 Sep & 0.06802 & 25.96 \\
1 Sep & 0.06854 & 27.79 & & & 9 Sep & 0.06767 & 26.1 \\
\hline 2 Sep & 0.0716 & 27.55 & 9 & 10.92 & 10 Sep & 0.06906 & 25.98 \\
3 Sep & 0.07518 & 26.4 & 27 & 19.97 & 11 Sep & 0.06826 & 25.91 \\
4 Sep & 0.07829 & 25.86 & 10 & 0.01 & $12 \mathrm{Sep}$ & 0.06988 & 25.44 \\
5 Sep & 0.08659 & 25.74 & 6 & 1.11 & $13 \mathrm{Sep}$ & 0.06833 & 25.49 \\
6 Sep & 0.08303 & 25.96 & & & $14 \mathrm{Sep}$ & 0.06937 & 26.24 \\
7 Sep & 0.0812 & 25.92 & & & & & \\
\hline
\end{tabular}

(1 day prior to the passage), 3 September (storm passage), and 4-5 September (poststorm). The highlighted box in Table 2 represents numerical data for the target area of maximum wind speeds, the averages of accumulated precipitation, SST, and Chl- $a$. Surface winds were analyzed to study how the forcing of Hurricane Earl influenced the mixed layer of the region. For consistency, daily precipitation was observed between 0000 and 1200 UTC and wind observations were at 0600 UTC.

The initial start date of the analysis was on 2 September, which signifies prestorm conditions slightly influenced by the approaching hurricane. Recalling from the SST and Chl- $a$ section, increased Chl- $a$ concentrations initially occurred 1 day prior to the passage of Earl. This feature was investigated by examining the wind field and accumulated precipitation, which suggests that the additional abundance of Chl- $a$ was most likely the result of surface winds $\left(9 \mathrm{~m} \mathrm{~s}^{-1}\right)$ and heavy rainfall $(10.9 \mathrm{~mm})$ near the coast.

\subsubsection{Precipitation and wind field}

The passage of Earl occurred on 3 September as shown by large wind fields and dark regions of precipitation (Figure 9). Within $24 \mathrm{~h}$, a total cooling in SST of $1.0^{\circ} \mathrm{C}$ was observed, which is distinguishable by the widespread yellow color in the target region (Figure 6). Precipitation on this date was localized near the North Carolina coastline. As noted, previous studies determined that heavy rainfall from tropical cyclones could cause runoff of sediments from land to water (Zhao et al. 2009). In this event, the amount of Chl- $a$ could have increased as the discharge of stormwater was transported to the ocean. Furthermore, the increase in Chl- $a$ in the following days (4-5 September) is concentration in the region which accumulated large amounts of rainfall within close proximity to land. This further validates our theory of expecting larger concentrations along coastal regions in contrast to open-bodied waters.

Examining the wind field from 2 to 5 September displayed variability with a maximum value occurring on 3 September $\left(\sim 27 \mathrm{~m} \mathrm{~s}^{-1}\right)$. The following days (4-5 

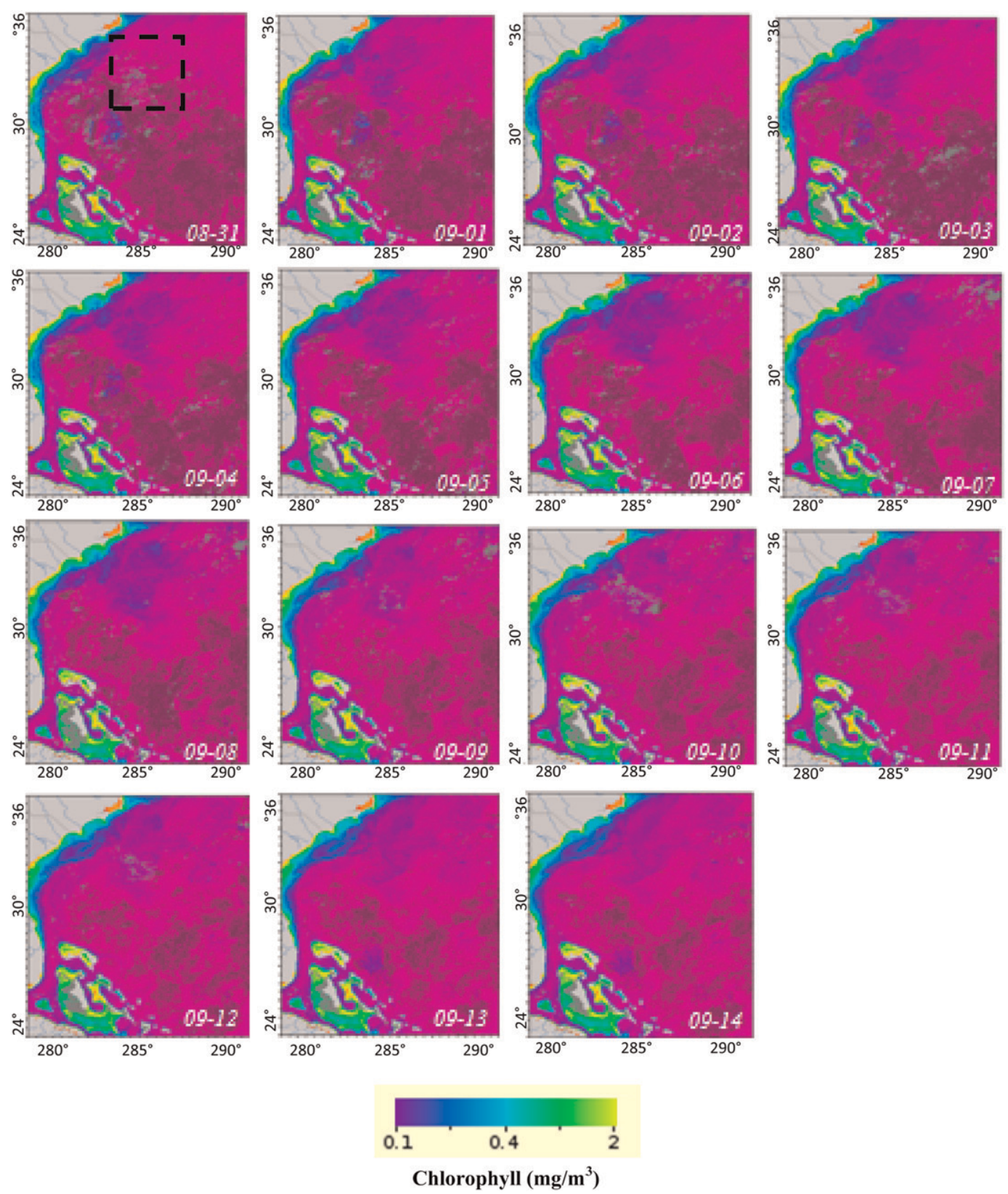

Figure 7. The 8-day composite imagery of chlorophyll derived from satellite data from Aqua MODIS. Dates include 31 Aug-14 Sep 2010 for the case study of Hurricane Earl. The boxed area represents the location that exhibited large changes in chlorophyll concentrations.

September) showed moderately weakening forces (e.g., 10 and $6 \mathrm{~m} \mathrm{~s}^{-1}$, respectively) and changes in ocean color for SST (yellow color) and Chl- $a$ (dark blue color). We believe that this response was directly correlated to the feedback of the storm and, in particular, strong wind shear. 
(a)

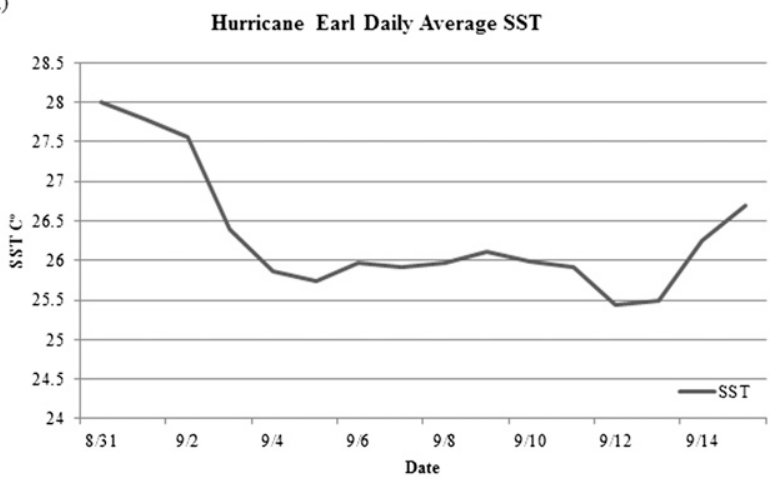

(b)

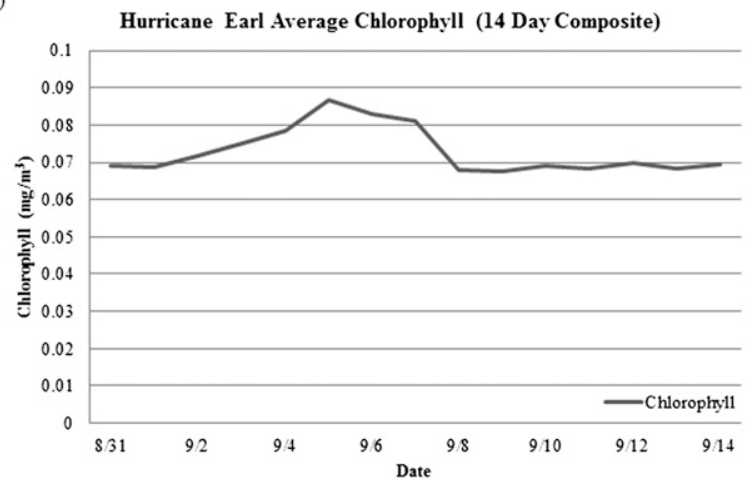

Figure 8. (a) Averaged daily SST and (b) averaged daily Chl-a for boxed area for Hurricane Earl from 30 Aug to 15 Sep 2010.

\section{Conclusions}

The present study examined various contributing factors that induced the abundance of phytoplankton blooms following the events of tropical cyclones in the Atlantic and Pacific basins. The results showed that accumulated biomass was exclusively attributed to the response of storm passage as indicated by SST and Chl- $a$ fluxes. A scientific understanding of studied parameters provided evidence of a correlation between oceanic basins as represented by numerical and satellitederived data.

Significant similarities for both cases included the following: trends of initial cooling SST and increasing Chl- $a$, response time, opposing variations (SST versus Chl- $a$ ), and prestorm Chl- $a$ increases. Figure 10 demonstrates the inverse correlations of SST and Chl- $a$ for both events. The inverse correlation coefficients are -0.67 and -0.26 for Xangsane and Earl, respectively. Likewise, examination of storm-generated surface winds and precipitation (4-day comparison) provided additional supporting evidence for the entrainment of phytoplankton blooms following the wake of Typhoon Xangsane (2006) and Hurricane Earl (2010).

Similarities and differences were evident from analysis of the inverse correlation plots (Figure 10). The most notable difference is the variation in Chl- $a$ among basins. According to Mei et al. (Mei et al. 2012), the feedback response of SST cooling following the wake of a storm can be dependent on the rate of translation 
Surface Wind
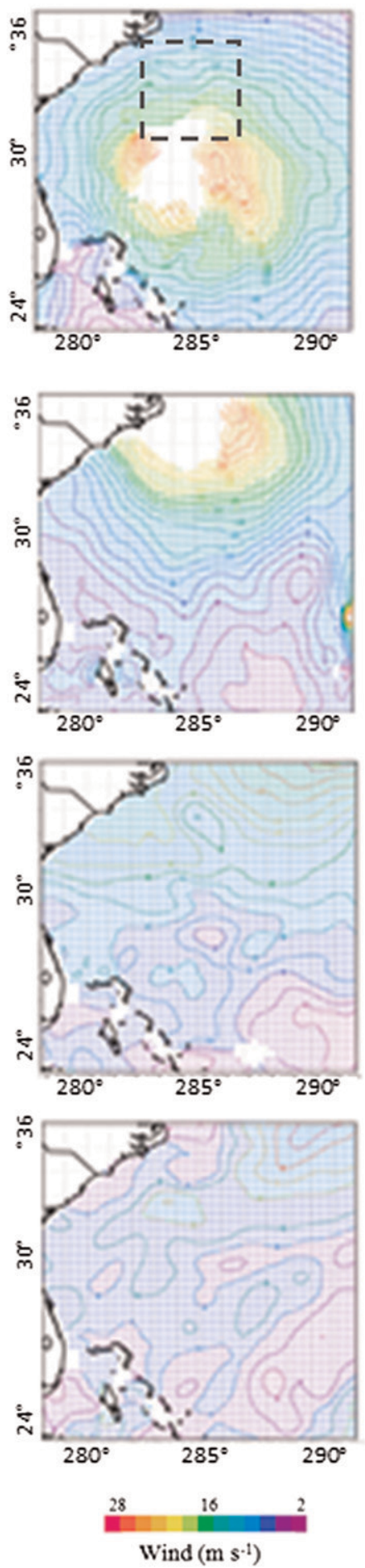

Precipitation
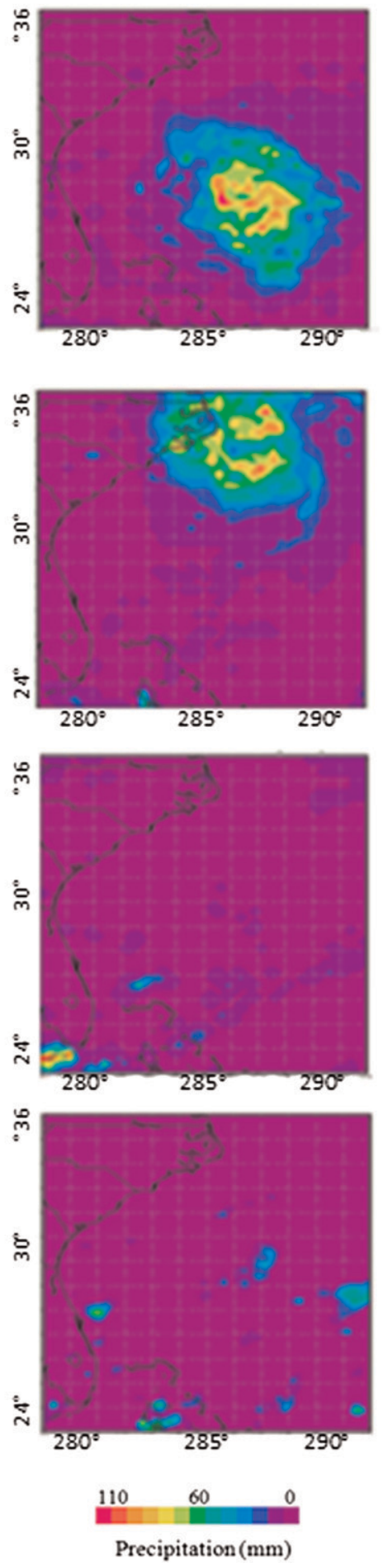

Figure 9. A 4-day comparison of precipitation based on the TRMM Real-Time Multisatellite Precipitation Analysis for experimental 3-hourly rainfall, with surface winds generated by the Blended Sea Winds, for the passage of Hurricane Earl from 2 to 5 Sep 2010. 

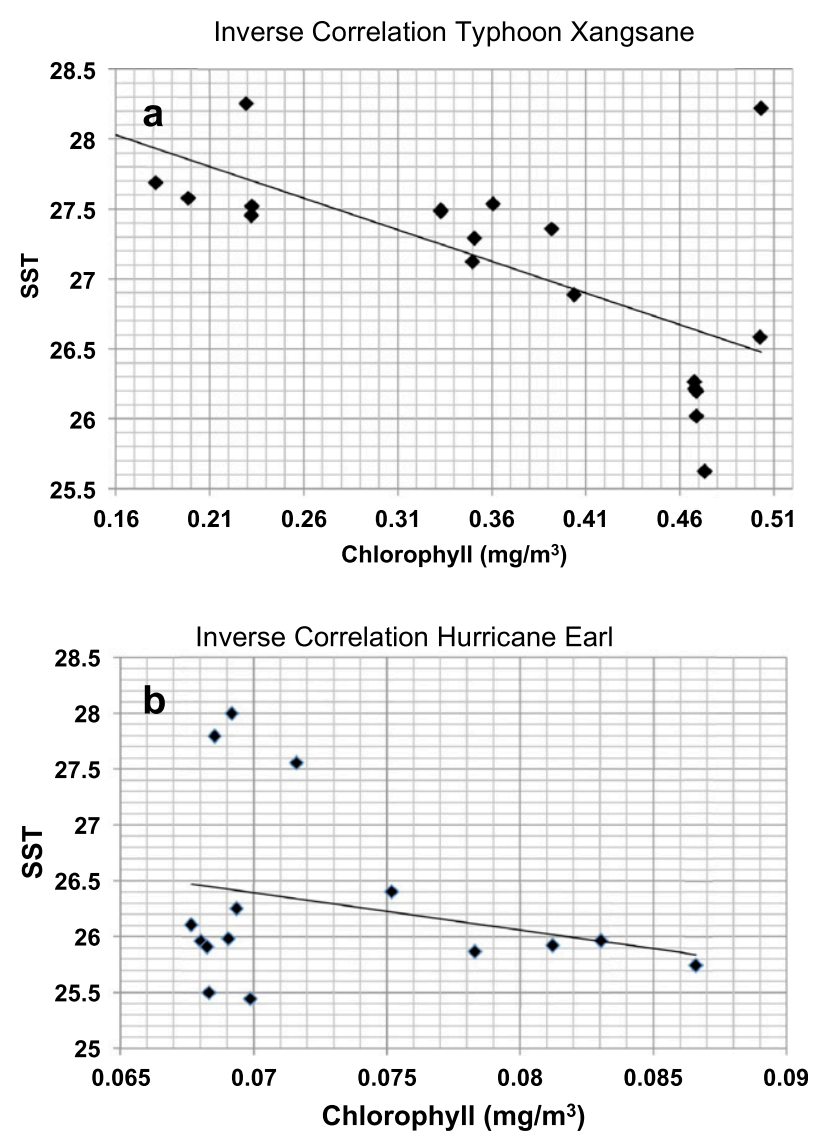

Figure 10. Correlation of SST and Chl-a for (a) Typhoon Xangsane (2006) and (b) Hurricane Earl (2010).

speed (storm motion). Furthermore, their research suggests that fast-moving tropical cyclone events produce less significant negative SST cooling affects than exhibited by slow-moving storms. This is evident from our research when comparing the rate of SST cooling and Chl- $a$ fluxes between Xangsane and Earl. Notably, Typhoon Xangsane's translational speed was respectively slow moving as exhibited in our sectioned box and showed a cooling feedback of $-2.6^{\circ} \mathrm{C}$ and $+0.24365 \mathrm{mg} \mathrm{m}^{-3}$ within a 4-day period (Table 1). In contrast, Hurricane Earl exhibited a fast-moving translation speed, which resulted in a lower cooling feedback response of $-1.8^{\circ} \mathrm{C}$ and $+0.01499 \mathrm{mg} \mathrm{m}^{-3}$ within a 4-day period (Table 2). Additional parameters that may further validate our results include topography, currents, and seasonal changes within the water column; however, this analysis is beyond the scope of our study.

Overall, findings from this study document and provide evidence that variables surrounding a tropical cyclone event can induce the quantity of biological substances regardless of oceanic location. Further scientific literature that examines additional case studies (within similar and different sample regions), under the same experimental procedures and numerical experiments, 
Earth Interactions • Volume 17 (2013) • Paper No. 17 • Page 18

may be beneficial for better understanding the overall feedback response of tropical cyclone events.

Acknowledgments. We acknowledge the suppliers of datasets employed here. Thanks are also given to Dr. Danling Tang of the South China Sea Institute of Oceanology for suggestions. The manuscript proofread by Christopher Bonanno is also appreciated. Please note that the findings and views discussed in this paper are not endorsed by or affiliated with Covance, Inc.

\section{References}

Acker, J., P. Lyon, F. Hoge, S. Shen, M. Roffer, and G. Gawlikowski, 2009: Interactions of Hurricane Katrina with optically complex water in the Gulf of Mexico: Interpretation using satellite-derived inherent optical properties and chlorophyll concentrations. IEEE Geosci. Remote Sens. Lett., 6, 209-213.

Ahmad, A., and S. Quegan, 2012: Cloud masking for remotely sensed data using spectral and principal components analysis. Eng. Technol. Appl. Sci. Res., 2, 221-225.

Babin, S. M., J. A. Carton, T. D. Dickey, and J. D. Wiggert, 2004: Satellite evidence of hurricaneinduced phytoplankton blooms in an oceanic desert. J. Geophys. Res., 109, C03043, doi:10.1029/2003JC001938.

Basterretxea, G., E. D. Barton, P. Tett, P. Sangrá, E. Navarro-Perez, and J. Arístegui, 2002: Eddy and DCM response to wind-shear in the lee of Gran Canaria. Deep-Sea Res., 49, 10871101.

Cangialosi, J. P., and J. L. Franklin, 2012: National Hurricane Center forecast verification report. National Hurricane Center Rep., 76 pp.

Diersing, N., 2009: Phytoplankton blooms: The basics. NOAA/Florida Keys National Marine Sanctuary Rep., 2 pp. [Available online at http://floridakeys.noaa.gov/scisummaries/wqbloom. pdf.]

Dunbar, B., cited 2011: NASA hurricanes/tropical cyclones latest storm images and data. [Available online at http://www.nasa.gov/mission_pages/hurricanes/archives/2006/h2006_xangsane. html.]

Emelyanov, E. M., 2005: The Barrier Zones in the Ocean. Springer, 632 pp.

Hanshaw, M. N., M. S. Lozier, and J. B. Palter, 2008: Integrated impact of tropical cyclones on sea surface chlorophyll in the North Atlantic. Geophys. Res. Lett., 35, L01601, doi:10.1029/ 2007GL031862.

Jacob, S. D., and L. K. Shay, 1999: Upper ocean response to tropical cyclone wind asymmetries. Proc. Workshop on Extratropical Transition of Tropical Cyclones, Kaufbeuren, Germany, World Meteorological Organization.

— , and C. J. Koblinsky, 2007: Effects of precipitation on upper-ocean response to a hurricane. Mon. Wea. Rev., 135, 2207-2225.

Katara, I., J. Illian, G. J. Pierce, B. Scott, and J. Wang, 2008: Atmospheric forcing on chlorophyll concentration. Hydrobiologia, 612, 33-48.

Lana, A. D., 2007: 2006 annual tropical cyclone report. U.S Naval Maritime Forecast Center/Joint Typhoon Warning Center Rep., 98 pp.

Lin, I., and Coauthors, 2003: New evidence for enhanced ocean primary production triggered by tropical cyclone. Geophys. Res. Lett., 30, 1718, doi:10.1029/2003GL017141.

Livingston, R., 2007: Phytoplankton bloom effects on a gulf estuary: Water quality changes and biological response. Ecol. Appl., 17, S110-S128.

Mei, W., C. Pasquero, and F. Primeau, 2012: The effect of translation speed upon the intensity of tropical cyclones over the tropical ocean. Geophys. Res. Lett., 39, L07801, doi:10.1029/ 2011GL050765. 
MODIS Atmosphere, cited 2013: Cloud mask. [Available online at http://modis-atmos.gsfc.nasa. gov/MOD35_L2/index.html.]

Monaldo, F. M., T. D. Sikora, S. M. Babin, and R. E. Sterner, 1997: Satellite imagery of sea surface temperature cooling in the wake of Hurricane Edouard (1996). Mon. Wea. Rev., 125, 27162727.

NASA, cited 2011a: JPL OurOcean Portal. [Available online at http://ourocean.jpl.nasa.gov/.]

— Satellite Precipitation Analysis (TMPA-RT): 3B42RT. [Available online at http://disc2. nascom.nasa.gov/Giovanni/tovas/realtime.3B42RT.2.shtml.]

NOAA ERDDAP, cited 2011: SST, Аqua MODIS, NPP, Indonesia, daytime (14 day composite). [Available online at http://coastwatch.pfeg.noaa.gov/erddap/griddap/erdMPsstd14day.graph.]

Price, J. F., 1981: Upper ocean response to a hurricane. J. Phys. Oceanogr., 11, 153-175.

Shi, W., and M. Wang, 2007: Observations of a Hurricane Katrina-induced phytoplankton bloom in the Gulf of Mexico. Geophys. Res. Lett., 34, L11607, doi:10.1029/2007GL029724.

Son, S., T. Platt, C. Fuentes-Yaco, H. Bouman, E. Devred, and Y. Wu, 2007: Possible biogeochemical response to the passage of Hurricane Fabian observed by satellites. J. Plankton Res., 29, 687-697.

Subrahmanyam, B., K. H. Rao, N. S. Rao, V. S. N. Murty, and R. J. Sharp, 2002: Influence of a tropical cyclone on chlorophyll-a concentration in the Arabian Sea. Geophys. Res. Lett., 29, 2065, doi:10.1029/2002GL015892.

Wang, D., and H. Zhao, 2008: Estimation of phytoplankton to Hurricane Gonu over the Arabian Sea based on ocean color data. Sensors, 8, 4878-4893.

Weather Underground, cited 2013a: Major Hurricane Earl. [Available online at http://www. wunderground.com/hurricane/at20105.asp?MR=1.]

_ hurricane/wp200619.asp?MR=1.]

Zhang, H. M., and J. J. Bates, 2011: Blended Sea Winds. [Available online at http://www.ncdc.noaa. gov/oa/rsad/air-sea/seawinds.html.]

Zhao, H., D. Tang, and X. Wang, 2009: Phytoplankton blooms near the Pearl River estuary induced by Typhoon Nuri. J. Geophys. Res., 114, C12027, doi:10.1029/2009JC005384.

Zheng, G. M., and D. Tang, 2007: Offshore and nearshore chlorophyll increases induced by typhoon winds and subsequent terrestrial rainwater runoff. Mar. Ecol. Prog. Ser., 333, 61-74.

Earth Interactions is published jointly by the American Meteorological Society, the American Geophysical Union, and the Association of American Geographers. Permission to use figures, tables, and brief excerpts from this journal in scientific and educational works is hereby granted provided that the source is acknowledged. Any use of material in this journal that is determined to be "fair use" under Section 107 or that satisfies the conditions specified in Section 108 of the U.S. Copyright Law (17 USC, as revised by P.IL. 94553 ) does not require the publishers' permission. For permission for any other from of copying, contact one of the copublishing societies. 